\title{
Virtualization of Clothing Thermal Comfort in 3D Simulations
}

\author{
Sertaç Güney ${ }^{1 *}$ \\ ${ }^{\mathbf{1} S e l c ̧ u k ~ U n i v e r s i t y, ~ F a c u l t y ~ o f ~ A r c h i t e c t u r e ~ a n d ~ D e s i g n, ~ H a n d i c r a f t s ~ D e p a r t m e n t, ~ K o n y a, ~ T u r k e y(O R C I D: ~ 0000-0002-9301-0026), ~ s e r t a c . g u n e y @ s e l c u k . e d u . t r ~}$
}

(1st International Conference on Applied Engineering and Natural Sciences ICAENS 2021, November 1-3, 2021)

(DOI:10.31590/ejosat.979644)

ATIF/REFERENCE: Güney, S. (2021). Virtualization of Clothing Thermal Comfort in 3D Simulations. European Journal of Science and Technology, (28), 29-33.

\begin{abstract}
Virtual simulations have become a part of design and marketing from personal use to professional designs and provide virtual realism to a great extent. With rapidly developing technology, nowadays it has attracted much more attentions especially in textile processes. The 3D virtual garment simulation provides the textile producers and fashion designers with benefits in terms of product development, customization of garments and speed to market. While most of the software focuses just on visual design, some major software manufacturers (Lectra, Optitex, Gerber, etc.) try to develop programs to accurately simulate fabric behavior as well as visual modeling. When the literature studies are examined, it is seen that the simulations in which the fabric mechanical and physical properties are defined, provide virtual realism to a large extent. But this is just regarding to the ergonomic comfort of the garment and virtually no garment simulations exist for the realistic prediction of thermal comfort. The estimation of clothing thermal comfort is very helpful for designing garments, especially sports and works garments where thermal comfort plays an crucial role for the status of the wearer. To make a method to realistic solution to virtualize the thermal comfort of clothing: virtual body properties, garment design, clothing drapability, thermal characteristics of fabric and the thermoregulation of the human body according to different conditions should be considered all together.
\end{abstract}

Keywords: Thermal comfort, virtualization, virtual garment, thermal imaging, 3D simulation

\section{Giysi Termal Konforunun Üç Boyutlu Simülasyonlarda Sanallaştırılması}

\section{Öz}

Sanal simülasyonlar, kişisel kullanımdan profesyonel tasarımlara kadar tasarım ve pazarlamanın bir parçası haline gelmiştir ve büyük ölçüde sanal gerçeklik sağlamaktadır. Hızla gelişen teknoloji ile günümüzde özellikle tekstil proseslerinde bu tür yazılımlar çok daha fazla ilgi görmektedir.Üç boyutlu sanal giysi simülasyonu, tekstil üreticilerine ve moda tasarımcılarına ürün geliştirme, giysilerin özelleştirilmesi ve piyasaya sürülme hızı açısından avantajlar sağlamaktadır.Yazılımların çoğu sadece görsel tasarıma odaklanırken, bazı büyük yazılım üreticileri (Lectra, Optitex, Gerber, vb.) görsel modellemenin yanı sıra kumaş davranışını doğru bir şekilde simüle etmek için programlar geliştirmeye çalışmaktadırlar.Literatür çalışmaları incelendiğinde kumaşın mekanik ve fiziksel özelliklerinin tanımlandığı simülasyonların büyük ölçüde sanal gerçeklik sağladığı görülmektedir. Ancak bu sadece giysinin ergonomik konforu ile ilgilidir ve termal konforun gerçekçi tahmini için neredeyse hiçbir giysi simülasyonu yoktur. Giysilerin termal konforunun tahmini, giysilerin, özellikle de termal konforun kullanıcının durumu için çok önemli bir rol oynadığı spor ve iş giysilerinin tasarlanmasında çok yararlıdır. Giysilerin termal konforunu sanallaştırmak için gerçekçi bir çözüm yöntemi hazırlamak için: sanal vücut özellikleri, giysi tasarımı, giysi dökümlülüğü, kumaşın termal özellikleri ve insan vücudunun farklı koşullara göre termoregülasyonu birlikte düşünülmelidir.

Anahtar Kelimeler: Termal konfor, sanallaştırma, sanal giysi, termal görüntüleme, 3D simülasyon

*Sorumlu Yazar:Selçuk University, Faculty of Architecture and Design, Handicrafts Department, Konya, Turkey, ORCID: 0000-0002-93010026,sertac.guney@selcuk.edu.tr 


\section{Introduction}

Garment design and proceeding is a highly specialized field which needs design creativity, skills of technical pattern making, knowledge of manufacturing techniques in addition to an evaluation of fabric science and performance [1]. In designing and manufacturing clothes, there is a need of capable fashion designer to create garment patterns, try on mannequins to assess the fitting and drape, and suitablely correct the design according to the demands. This line makes the design of garment a complex process with several restrictions which significantly limit the designer's creativity. In this regard, virtual simulation of garments is a great solution for fashion designers not only to speed up the steps in their creation of garment, but also to bring their designs to life through high quality mechanical simulation via animations.

Virtual garment is a process used for speeding up the presention of the collections to new markets and reducing the overall cost. It allows designers to design easily with a variety of fabrics and patterns on a $3 \mathrm{D}$ virtual body without manufacturing the sample garment; it enables to use of a virtual model, for evaluating and testing the characteristics of a product and for simulating the manufacturing processes in a computational environment [2]. Figure 1 shows process steps of 3D virtual garment simulation including creating pattern, arranging the virtual body, defining fabric properties, sewing garment and simulating.

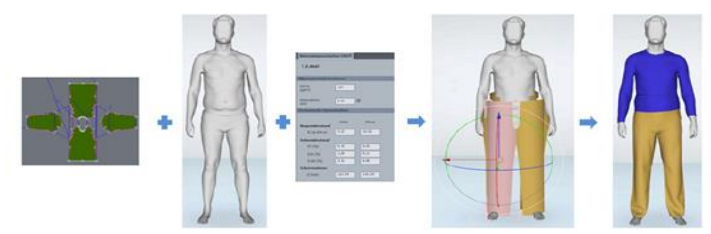

Figure 1. Process steps of $3 D$ virtual garment simulation

The realistic look of cloth was the first focus; however virtual garment simulation soon evolved toward the realistic simulation of the mechanical behaviors of cloth. Although there are still some deficiencies in virtual garment simulations, researches and improvements are still ongoing.

In 1980s, the researches on 3D human modelling and virtual try-on started to draw attention mainly for the cinematic applications. Then, different systems having both geometric and physical based approaches for 3D virtual try-on simulation have been developed in order to improve the accuracy and speed.

In earlier past, the fashion market somehow did not adopt the virtual pattern design process due to the inaccuracy of results in virtual try-on simulations. To overcome these misunderstandings, 3D simulation systems should properly simulate fabric behaviors in addition to predicting the garment shapes correctly on a virtual model. Using the same fabric in different grain alignments or different fabrics contributes to the draping effects. This is because clothing fabrics have significant influence on the resulted garment shapes. The draping effects of different fabrics can be virtualized by considering the fabric material properties obtained by laboratory test or individual measurement kits of simulations [3]. When the literature studies are examined, it is seen that the simulations in which the fabric mechanical and physical properties are defined, provide virtual realism to a large extent [1,4-6]. But this is just regarding to the ergonomic comfort of the garment and virtually no garment simulations exist for the realistic prediction of clothing thermal comfort. In this research, we have focused on the important factors to consider in virtualization of clothing thermal comfort and have pointed out the feasibility of adapting of thermal imaging into virtual garment simulations.

\section{Clothing Thermal Comfort}

Thermal comfort has every time been an important factor in garment design. The human body always operates to maintain its core body temperature within a temperature range of $37 \pm 0.5^{\circ} \mathrm{C}$ achieved by heat production and heat loss to the environment. The human body continuously produces heat due to its metabolism. The metabolism rate depends upon the activity level of the human [7].

Clothing plays a key role to manage the heat stability of the human body within environment because it significantly changes heat and mass transfer between body and environment. The thermal insulation, air permeability, and water vapor resistance of clothing are the most significative factors in terms of thermal comfort [8-9]. Thermal comfort being a key factor [10] is determined by thickness, fabric and yarn structure, the number of layers, the drape behavior of fabrics, and most importantly, air gaps between body and clothing layers [11].

3D simulation systems may provide an opportunity for fashion design with their output for thermal simulation of clothing performance. Firstly it is need of accurate simulation of air gap thickness and contact area between garment and skin, since these parameters specify the heat and mass transfer through the clothing [12]. The process steps in virtual garment simulation have a strong influence on outputs which are related to air gap thickness and contact area. The important factors have been considered in four groups: Virtual body (avatar), Garment fit, Fabric and Environmental factors.

\subsection{Virtual Body (Avatar)}

Prototypes production for the assessment of the garment fit is time-consuming and costly. The virtual fit allows a designer to test the garments before their real production. 3D software is used to virtually design and simulate the garment as the real prototype. The "virtual fit" of patterns on the human body can be evaluated and modified to improve the garment fit and the simulation can be changed accordingly for re-evaluation [13]. Body posture and shape are the major factors that influence the fit and satisfaction with clothing [14]. Garment poses on body parts and moves along with body movements so these factors affect the accuracy of virtual garment simulation. The virtual human body based on 3D anthropometry has conventionally been created by two methods: (1) the direct avatar, using 3D body scan form and (2) the manual avatar, using the body measurement. Many studies have been conducted on direct and manual virtual avatars in respect of garment fit [15-17].

With the current virtual try-on technology, the direct virtual avatar created from 3D body scan data of the customers ensures more precise fit and appearance in wearing virtual garments. It has an asymmetric body shape and realistic differences in body types and proportions. The manual virtual avatar can 
accommodate symmetric body shapes however, the entry of human body measurements cannot support various real body shapes. Figure 2 presents the direct avatar image (a) created through body scan data, and the manual avatar (b) created by the body measurements.
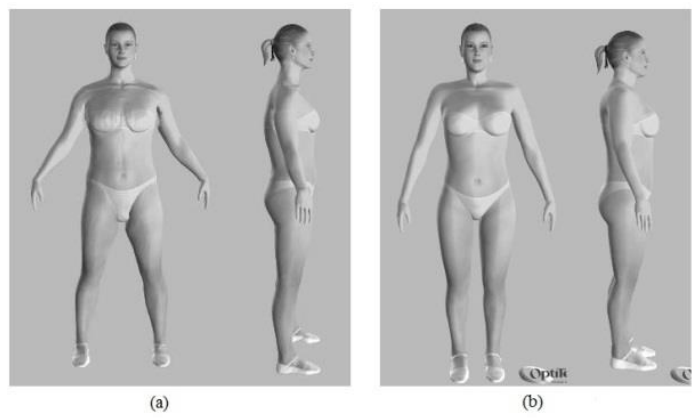

\section{Figure 2. Direct avatar (a), Manuel avatar (b) [17]}

Another important factor is body tissue. The tissues of the human body are anisotropic and nonlinear under pressure. The tissue layer thickness has a great effect on how the body behaves while contacting [18]. Especially it is more important in compression garment design. Because the compression garment exerts pressure on body part and make the body contours change under pressure.

In assessment of thermal comfort, the virtual body properties may affect the contact area and air gap thickness which has a significant effect on the heat transfer mechanism of human body and has irregular distribution throughout the body. Also asymmetric body shapes and concave contours effect contact area and the air gap thickness so it change the thermal insulation characteristics of garment.

\subsection{Garment Fit}

Garment design, contact area and the air gap thickness between skin and garment are very crucial factors for mass and heat transfer in clothing. So, by a suitable adjustment of ease allowances, fabric draping and pattern cuts, the thermal and moisture management in garment can be under control. The knowledge of how much these parameters effect will provide the accurate simulation of the mass and heat transfer through clothing, and subsequently, thermo-physiological reaction and human perceptual [19].

The non-uniform thickness of the air layers effects the local heat and vapor transmision. These parameters changes not only due to the air gap thickness but also to whether the garment surface is bended or flat [20]. The behavior of garment surface is related to the fabric draping and pattern.

The distribution of the air layer thickness was researched with $3 \mathrm{D}$ body scanning techniques. To measure the air gap thickness, 3D scans of the body with and without garment were compared and the air gap thickness was calculated from either selected points or from cross sections through the dressed body [21-22].

3D virtual garment simulation tools offer an opportunity to use their output for thermal virtualization of clothing performance. The accuracy of determining air gap thickness distribution in 3D garment simulation software was investigated in many researches [19, 23-25]. The results show that 3D simulation software is capable of showing the differences in air gap thickness obtained from the virtual try-on over body parts. The distribution in the air gap thickness of virtual try-on over body regions showed the same aspect as the real garments.

The air gap thickness and the contact area were substantially dependent on the ease allowances in clothing considerably varied in the overall garment fit. Especially in specific parts of body. Figure 3 shows the effect of garment fit and concave body parts on air gap thickness and contact area [26].

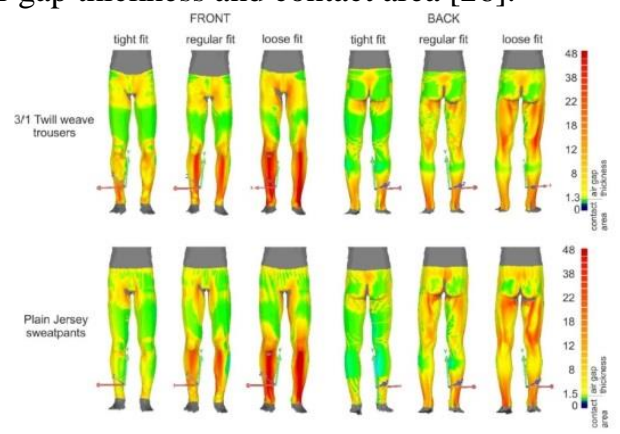

Figure 3. Color maps of 3D scans of trousers and sweatpants in loose, regular and tight fits for front and back view [26]

\subsection{Fabric}

The main approaches meeting the challenges of virtual garment simulation are accurate representation of human body model and realistic simulation of garment drape on an avatar [27]. Accurate simulation of garment drape is related by inputting the right parameters of fabric. Using the accurately derived mechanical and physical fabric properties, the garment follows the movement of the virtual mannequin during simulation [28].

The fabric type and its drapability also have effects on the size of the contact area and air gaps in clothing. The effect of the drapability is related to the size of ease allowances in clothing and, hence, it is clear that the looser the garment become, the more influence of the garment drape on the air gap thickness is observed [29].

Heat and mass transfer through the garment is not only dependent on the contact area and the air gap thickness but also on the structural, physical and thermal properties of fabrics used in the garment fabric (e.g., fiber type, yarn type, fabric thickness, weave type, thermal resistance, vapor resistance, air permeability). The physical and mechanical properties can be defined in virtual garment simulations but so far, thermal characteristics of fabric could not be defined in any virtual garment simulation. Currently, no virtual garment simulation has a capability to make a thermo-physiological model by inputting measured thermal parameters of fabric. Thermal characteristics of fabric can be estimated by an index defined in measurable parameters related to the thermal comfort. Recently, some researchers investigated the thermal comfort estimation by creating comfort indexes [30-33].

Matusiak (2010), in his study, created a thermal comfort index (TCI) based on some thermal properties of fabrics. 


$$
\mathrm{TCI}=\sum_{i=1}^{n} a_{x} \frac{x_{i}-x_{i \min }}{x_{i}}+\sum_{j=1}^{m} a_{z} \frac{z_{j \max }-z_{j}}{z_{j \max }}
$$

where:

TCI - Thermal Comfort Index,

xi - value of the ith property, whose increment causes an improvement in thermal comfort; $i=1,2, \ldots, n$,

xi min - minimum value of property xi acceptable from the point of view of thermal comfort,

$\mathrm{zj}$ - value of the jth property, whose reduction causes an improvement in thermal comfort; $j=1,2, \ldots, m$,

$\mathrm{zj}$ max - maximum value of the property $\mathrm{zj}$ acceptable from the point of view of thermal comfort,

In the thermal comfort index, it has divided the effective parameters into two groups as positive effect and negative effect properties. Using the values of thermal resistance (R), thermal absorbency (b), water vapor resistance (Ret) and air permeability (AP) from fabric thermal measurements, it obtained thermal comfort index values ranging between 0 and 1 of nine different fabrics. In this calculation, the lowest and highest values were determined from the values in the fabric group used. He has determined the severity rating of the properties between 1 and 5 . He stated that the thermal comfort index based on the importance of some comfort properties of the fabric can be used in thermal comfort estimation of the clothes produced from these fabrics [33].

\subsection{Environmental factors}

The human body manages its core body temperature within a certain temperature range of $37 \pm 0.5^{\circ} \mathrm{C}$ by controling internal heat gain and heat loss to the environment. The ambient temperature, air velocity and humidity that affect thermal comfort are changing around body and clothing. The heat loss through the fabric mainly consists of convection and radiation. The airflow causes convective heat loss. This convective heat loss and the radiant heat exchange between the fabric surface and environment should be described. In recent software, the environmental factors are defined in some standards (Ashare-55, ISO 7730).

For virtual garment application, sometimes there is need to estimate the garment in variable conditions. Especially in sport wears, the environmental factors should be considered in respect of user's performance. Environmental temperature, humidity and air velocity can affect the mechanical and thermal behaviors of fabrics so the changes also can affect the results of simulations. isolation are particularly discouraged.

\section{Conclusions}

In this research, we have focused on the important factors to consider in virtualization of clothing thermal comfort and have pointed out the feasibility of adapting of thermal imaging into virtual garment simulations. In recent virtual garment simulations, they have sufficient capability to estimate mechanical behaviors and correspondingly drapability of fabric. In many researches, the results of virtual garment simulations were proved with regard to realistic prediction of air gap thickness and contact area. These results may offer an opportunity to develop thermal simulation of clothing e-ISSN:2148-2683 performance. However heat and mass transfer through the garment is not only dependent on the contact area and the air gap thickness but also on the structural, physical and thermal properties of fabrics used in the garment fabric (e.g., fiber type, yarn type, fabric thickness, weave type, thermal resistance, vapor resistance, air permeability). So all these factor should be considered in one process.

The virtual garment simulations can be improved using thermo-physiological model by inputting measured thermal parameters of fabric. Using the values of thermal resistance (R), thermal absorbency (b), water vapor resistance (Ret) and air permeability (AP) from fabric thermal measurements, a thermal comfort index can be obtained to estimate thermal comfort of garment.

Thermal mapping can be adapted to simulation by evaluating the fabric behaviors under extended states according to the output (strain maps etc.) of simulation. The values of thermal resistance values can be predicted under extended states and the thermal transfer performance of fabric can be investigated then the temperatures of fabric surface can be predicted as thermal imaging process.

The estimation of clothing thermal comfort is very helpful for designing garments, especially sports and works garments where thermal comfort plays an crucial role for the status of the wearer. To make a method to realistic solution to virtualize the thermal comfort of clothing: virtual body properties, garment design, clothing drapability, thermal characteristics of fabric and the thermoregulation of the human body according to different conditions should be considered all together.

\section{References}

[1] Power, J., (2013), Fabric objective measurements for commercial 3D virtual garment simulation, International Journal of Clothing Science andTechnology, Cilt. 25, No. 6, 423-439s.

[2] Papachristou, E. and Bilalis, N., 2015, How to Integrate Recent Development in Technology with digital Prototype Textile and Apparel Applications, Marmara Journal of Pure and Applied Sciences, 1: 32-39.

[3] Wu, Y.Y., Mok, P.Y., Kwok, Y.L., Fan, J.T. and Xin, J.H., 2011, An Investigation on the Validity of 3D Clothing Simulation for Garment Fit Evaluation, International Conference on Innovative Methods in Product Desing, Proceedings of the IMProVe 2011, 463-468.

[4] Gürsoy, F., Doğan, S. ve Kılınç, N., (2016), Comparison of the try-ons of a garment produced from Rize Fabric (Feretiko) in actual and virtual environments. 7. Uluslararas1 İstanbul Tekstil Konferans1 (BEZCE 2016), 21- 23 Mart 2016, İstanbul.

[5] Lee, E. and Park, H., 2017, 3D Virtual Fit Simulation Technology: Strengths And Areas ofİmprovement For Increased Industry Adoption, International Journal of Fashion Design, Technology and Education, 10:1, 59-70.

[6] Porterfield, A. and Lamar, T.A.M., 2017, Examining The Effectiveness Of Virtual Fitting With 3D Garment Simulation, International Journal of Fashion Design, Technology and Education, 10:3, 320-330.

[7] Awais, M., Wendt, E. and Krzywinski, S., 2019, Analysis on Thermal Comfort of Clothing with Different Textile 
Materials through Thermal Simulation, Proceedings of 3DBODY.TECH, 2019, pp.127-136.

[8] Das, A. and Ishtiaque, S.M., 2014, Comfort Characteristics of Fabrics Containing Twist-less and Hollow Fibrous Assemblies in Weft, J. Text. Apparel, Technol. Manag., no. January 2014,

[9] Havenith, G., 1999, "Heat balance when wearing protective clothing," Ann. Occup. Hyg., vol. 43, no. 5, pp. 289-296.

[10] Tugrul, R.O, 2007, The Effect of ThermalInsulation of Clothing on Human Thermal Comfort, FIBRES Text. East. Eur., vol. 15, no. 2, pp. 67-72, 2007.

[11] Duncan, S., McLellan, T. and Dickson, E.G., Improving Comfort in Clothing. 2011.

[12] Psikuta, A., Jager, M., Mark, A., Mcgowan, H. Josji, A. and Kink, M., 2019, CLO3D Fashion Design Software - A Perspective for Virtual Thermal Modelling of Garments, Proceedings of 3DBODY.TECH 2019, pp. 126.

[13] Kim, D.-E. and LaBat, K. 2013, An Exploratory Study of Users' Evaluations of The Accuracy and Fidelity of A ThreeDimensional GarmentSimulation. Textile Research Journal, 83(2), 171-184.

[14] Tama, D.,\& Öndoğan, Z. (2014). FittingEvaluation of Pattern Making Systems According to Female Body Shapes. FIBRES \& TEXTILES in Eastern Europe, 22(4), 107-111.

[15] Spahiu, T., Shehi, E. and Piperi, E., 2015, Personalized Avatars For Virtual Garment Design And Simulation, International Journal of Education, Science, Technology, Innovation, Health and Environment, 1(3), pp.56-63.

[16] Lin, S., Johnson, R. and Kang, J., 2018, Journal of Education, Science, Technology, Innovation, Health and Environment, Journal of Textile Engineering \& Fashion Technology, 4(2), pp.124-129.

[17] Lim, H. and Istook, L., 2011, Comparative Assessment of Virtual Garments using Direct and Manual Avatars, The Research Journal of the Costume Culture, 12, pp.1359-1371.

[18] Harrison D., Fan, Y., Larionov, E. and Pai, D., 2018, Fitting Close-to-Body Garments with 3D Soft Body Avatars, Proceedings of 3DBODY.TECH 2018, pp.184-189.

[19] Psikuta, A., Mert, E., Annahelm, S. and Rossi, R., Local Air Gap Thickness And Contact Area Models For Realistic Simulation Of Human Thermo-Physiological Response, International Journal of Biometeorology, 62, pp.1121-1134.

[20] Mert, E., Psikuta, A., Bueno, M.A. and Rossi, R.M., 2015, Effect of Heterogenous and Homogenous Air Gaps on Dry Heat Loss Through The Garment. International Journal of Biometeorol, 59(11):1701-1710.

[21] Mert, E., Böhnisch, S., Psikuta, A., Bueno, M.A. and Rossi, R.M., 2016, Contribution of Garment Fit and Style to Thermal Comfort at the Lower Body. International Journal of Biometeorol, 60(12), pp.1995-2004.

[22] Mert, E., Psikuta, A., Bueno, M.A. and Rossi, R.M., 2017, The Effect of Body Postures on The Distribution of Air Gap Thickness and Contact Area. International Journal of Biometeorol, 61, pp.363-375.

[23] Mert, E., Psikuta, A., Arevalo, M., Charbonnier, C., LuibleBar, C., Bueno, M.A. and Rossi, R.M, 2017, Quantitative Validation of 3D Garment Simulation Software For Determination of Air Gap Thickness in Lower Body Garments, Materials Science and Engineering, 254, pp.1-5.

[24] Hu, P., Ho, E., Aslam, N., Komura, T. And Shum, H., 2019, A New Method To Evaluate TheDynamic Air Gap Thickness And Garment Sliding of Virtual Clothes During Walking, Textile Research Journal, 89 (19-20), pp.4148-4161.
[25] Mert, E., Psikuta, A., Arevalo, M., Charbonnier, C., LuibleBar, C., Bueno, M.A. and Rossi, R.M, 2017, A Validation Methodology and Application of 3D Garment Simulation Software To Determine The Distribution of Air Layers in Garments During Walking, Measurement, 117, pp.153-164.

[26] Mert, E., Böhnisch, S., Psikuta, A., Bueno, M.A., and Rossi, R.M., 2015, Determination of The Air Gap Thickness Underneath The Garment For Lower Body Using 3D Body Scanning, 6th International Conference on 3D Body Scanning Technologies, 27-28 October 2015, Lugano, Switzerland.

[27] Walter, L., Kartsounis, G.-A.,and Carosio, S., 2009, From 3D Design to 2D Patterns Involving Realistic Drape/Fit and Comfort Simulation. In Transforming Clothing Production into a -driven, Knowledge-based, High-tech Industry, pp. 232.

[28] Luible, C., and Magnenat-Thalmann, N. 2008, The Simulation of Cloth Using Accurate Physical Parameters. Tenth IASTED, International Conference on Computer Graphics and Imaging, pp. 123-128.

[29] Frackiewicz-Kaczmarek, J., Psikuta, A., Bueno, M.A., and Rossi, R.M., 2015, Effect of Garment Properties On Air Gap Thickness And The Contact Area Distribution, Textile Research Journal, 85 (18), pp.1907-1918.

[30] Hes, L., (2008), Non-Destructive Determination of Comfort Parameters During Marketing of Functional Garments And Clothing, Indian, Journal of Fbire and Textile Research, 33, 239-245.

[31] Matusiak, M. ve Sikorski, K., (2011), Relative Thermal Comfort Index as a Meaure of the Usefulness of Fabrics for Winter Clothing Manufacturing, Textile Research Institute, 19, 6(69), 94-100.

32] Bajzik, V., Hes, L. ve Dolezal, I., (2016), Changes in Thermal Comfort Properties of Sports Wear and Underwear due to Their Wetting, Indian Journal of Fbire and Textile Research, 41, 161-166.

[33] Matusiak, M., (2010), Thermal Comfort Index as a Method of Assessing the Thermal Comfort of Textile Materials, Textile Research Institute, 18, 2(79), 45-50.Space 10 pt 